\title{
Socio-demographic determinants of marital satisfaction in Jimma Zone, Southwest Ethiopia
}

\author{
Addisu Tegegn Bayle ${ }^{1 *}$, Dereje Wonde Ayalew ${ }^{2}$ and Asabneh Molla Yimer ${ }^{3}$ \\ ${ }^{1}$ School of Social Work, Jimma University, Ethiopia. \\ ${ }^{2}$ Sociology of Health and Wellbeing, Jimma University, Ethiopia. \\ ${ }^{3}$ Department of Sociology, Jimma University, Ethiopia. \\ Received 2 October, 2016; Accepted 8 November, 2016
}

\begin{abstract}
Marital satisfaction is one of the ingredients of marital stability and is affected by a number of factors. A cross-sectional survey substantiated with qualitative studies was conducted so as to identify the major socio-demographic factors that influence the marital satisfaction of married couples among selected districts of Jimma Zone, Oromia, Ethiopia. Study participants of $\mathbf{2 4 0}$ randomly selected couples, either the wife or husband, were surveyed and key informant interview was held to collect evidences about the study objectives. As a result, variables such as level of education, number of children, spousal infidelity, marriage type, leisure spending, interest difference, openness among couples, and poverty have brought a statistically significant difference in marital satisfaction. Similarly, qualitative study participants noted that economic background, educational background, type of marriage, religious background, ethnic background, age difference, place of birth, religious discordant marriage, migration, adultery, early marriage, Khat abuse, in-laws interference, family size, sexual incompatibility and polygamous marriage determine the marital satisfaction of couples in the study area. Besides, the study found out the existence of differences on the factors that shape the marital satisfaction of urban and rural couples.
\end{abstract}

Key words: Socio-demographic, marital satisfaction, determinants, Jimma Zone, Ethiopia.

\section{INTRODUCTION}

Marriage is a socially sanctioned relationship, usually involving economic cooperation, sexual activity, and childbearing (Macionis, 2008). Marriage, which exists everywhere though its type and functions vary from culture to culture, is a socially approved practice that served for the conception of family institution, which in turn is perceived as the building blocks of any society. The prevailing view towards marriage is that it is based on emotional attachment between the partners and entered into voluntarily (Mathews, 2002).
Notwithstanding, Brubaker and Kimberly (1993) argued that achieving marital satisfaction is not an easy issue. This suggests that a greater proportion of married couples have marriage relationship which can be characterized by uncertainty and instability. Consequently, there is the tendency to result in family disorganization, which is against the primary goal of family institution. This social pathology has been associated with high level of marital dissatisfaction (Parson and Bales 1955).The family experiences diverse

*Corresponding author. E-mail: addisu34@gmail.com.

Authors agree that this article remain permanently open access under the terms of the Creative Commons Attribution License 4.0 International License 
issues of psychological distress, financial lack to care for the children, communication between parents and children and emotional problems and frustration; resulting in depression, health problem and unfulfilled marital life (Adigeb and Mbua, 2015). Thus, marital satisfaction is considered as one predictor for marital stability.

Marital satisfaction is a mental state that reflects the perceived benefits and costs of marriage to a particular person. It is a multidimensional concept that includes different factors such as personality features, financial matters, child rearing styles, and sexual relations (Tazekand et al., 2013). Enquiry on marital satisfaction and the factors that influence marital satisfaction is vast and covers many areas relating to this topic. Couple's agreement on the style of relation, emotions expression, sexual relation, leisure time activities, home duties sharing, duration of being beside each other, external network and supply and incompatible explanations can affect marital satisfaction (Vangelisti and Huston 1994; Bradbury et al., 1996).

Moreover, Faulkner (2002) stated that demographic, psychological, marital process, gender-based, and life transitional predictors influence marital satisfaction and marital conflict for husbands and for wives over time. There is some support for gender-based influences on husbands and wives marital satisfaction and conflict. Similarly, Zianah et al. (2012) argued that demographic factors like length of marriage, presence of children, and gender highly influences marital satisfaction of couples. The study conducted by Adigeb and Mbua (2015) also suggested that psychological factors (depression, affection and sexual activities) and social factors (number of children, communication and time spent together) has significant relationship with marital satisfaction.

The previous studies on marital satisfaction and its determinants were either conducted in western societies or too timeworn. Accordingly, the existing studies could not able to adequately explain changes in the situation of the contemporary societies of developing countries. Moreover, the issue of marital satisfaction and the factors influencing it is a virgin area of research in Ethiopia in general and in Jimma Zone in particular. Consequently, this study was conducted to fill this knowledge gap by focusing on the socio-demographic determinants of marital satisfaction in Jimma Zone, Southwest Ethiopia.

\section{METHODOLOGY}

\section{Study participants}

The statistical community of this study consists of whole married couples in Jimma Zone. Accordingly, by considering the overall homogeneity in demographic, social and economic characteristics of the population, 240 samples were randomly recruited from four selected districts of Jimma Zone. In addition, there were also purposively selected key informants who were participated in the study to substantiate the quantitative data. Accordingly, four key informants from women and children affairs office, four key informants from justice office, and four elderly were included in the study.

\section{Data collection methods}

Survey questionnaire was used to collect from spouses regarding their perception and level of marital satisfaction and to identify the factors shaping marital satisfaction of couples. The researchers adapted ENRICH marital satisfaction scale to assess the level of marital satisfaction of respondents. The scale has 10 marital satisfaction items representing the diverse areas of marital relationship which includes personality issues, communication, conflict resolution, financial management, leisure activities, sexual relationship, children and parenting, family and friends, equalitarian roles and religious orientation. The researchers also conducted key informant interview with elders, experts in the court, professional experts from the selected districts' women and children's affairs office. From these concerned bodies a more detailed data were obtained to supplement the quantitative data. To facilitate the interview process, an interview guide was developed and used.

\section{Analysis approach}

Both quantitative and qualitative ways of analysing data were used. SPSS version 20.0 was employed to analyse the quantitative data and different statistical tests were used in line with their assumption. Descriptive statistics such as frequency distribution and mean as well as inferential statistics like T-test, ANOVA, and test of correlation were applied for the analysis endeavour. Thematic analysis was used for the qualitative information and was used to solidify and triangulate the quantitative data. Finally, the quantitative and qualitative data was analysed concurrently.

\section{RESULTS AND DISCUSSION}

\section{Socio-demographic characteristics of study participants}

Gender wise, $52.1 \%$ of the survey participants were female while $47.9 \%$ of them were males. In relation to the age distribution of respondents $24.2 \%$ and 38.8 of the participants were under the age range of 20 to 30 and 31 to 40 respectively. In addition, the age of the participants of the study ranges from 20 to 67 with the mean of 39.49 and standard deviation 9.956. Regarding the religious affiliation of respondents, $78.2 \%$ of the respondents were Muslims, $13.9 \%$ were orthodox Christians, 5.8 were Protestants, and $2.5 \%$ were Catholics. The employment status of respondents shows $31.2 \%$ and $17.9 \%$ were farmers and housewives respectively. In relation to participants' formal educational level, the majority (35\%) of them can't read and write, while $22.7 \%$ can read and write and $21.3 \%$ have attended primary education. Furthermore, about $52.9 \%$ of the respondents were living in rural areas while $47.1 \%$ of them were urbanites.

\section{Demographic and social-structural determinants of marital satisfaction}

Marital satisfaction among couples is determined by 
Table 1. Socio-demographic characteristics of respondents.

\begin{tabular}{|c|c|c|c|}
\hline Characteristics & Response & Frequency & Percentage (\%) \\
\hline \multirow{3}{*}{ Sex } & Male & 115 & 47.9 \\
\hline & Female & 125 & 52.1 \\
\hline & Total & 240 & 100 \\
\hline \multirow{6}{*}{ Age } & $20-30$ & 58 & 24.2 \\
\hline & $31-40$ & 93 & 38.8 \\
\hline & $41-50$ & 55 & 22.9 \\
\hline & $51-60$ & 31 & 12.9 \\
\hline & $61-70$ & 3 & 1.3 \\
\hline & Total & 240 & 100 \\
\hline \multirow{6}{*}{ Religious Affiliation } & Orthodox & 33 & 13.8 \\
\hline & Muslim & 186 & 77.5 \\
\hline & Protestant & 13 & 5.4 \\
\hline & Catholic & 6 & 2.5 \\
\hline & Missing & 2 & 0.8 \\
\hline & Total & 240 & 100 \\
\hline \multirow{9}{*}{ Employment status } & Self-employed & 31 & 12.9 \\
\hline & Full time employed & 30 & 12.5 \\
\hline & Daily labourer & 26 & 10.8 \\
\hline & Unemployed & 9 & 3.8 \\
\hline & Housewife & 42 & 17.5 \\
\hline & Farming & 73 & 30.4 \\
\hline & $\begin{array}{l}\text { Other (Petty trade, Support from others, } \\
\text { etc.) }\end{array}$ & 23 & 9.6 \\
\hline & Missing & 6 & 2.5 \\
\hline & Total & 234 & 97.5 \\
\hline \multirow[t]{7}{*}{ Educational status } & Can't read and write & 85 & 35.4 \\
\hline & Can read and write & 51 & 22.1 \\
\hline & Primary school & 54 & 22.5 \\
\hline & Secondary school & 22 & 9.2 \\
\hline & Tertiary school and above & 26 & 10.8 \\
\hline & Missing & 2 & 0.8 \\
\hline & Total & 238 & 99.2 \\
\hline \multirow{4}{*}{ Place of residence } & Rural & 126 & 52.5 \\
\hline & Urban & 112 & 46.7 \\
\hline & Missing & 2 & 0.8 \\
\hline & Total & 240 & 100 \\
\hline
\end{tabular}

various demographic and social-structural factors. This section attempted to present and discuss those factors shaping marital satisfaction.

\section{Gender and marital satisfaction}

Marriage is a highly gendered institution. Gender differences have been found in the household division of labour, parenting styles and responsibilities, the expression of sexual intimacy and in psychological orientation (Heaton and Blake, 1999). Men and women have different roles in marriage and view relationships through different eyes. As a result they most likely derive different benefits, perceive different costs and the advantages of marriage differently (Heaton and Blake, 
Table 2. Distribution of marital satisfaction by gender of respondents.

\begin{tabular}{lccccc}
\hline Sex & $\mathbf{N}$ & Mean (MS) & Standard deviation & \multicolumn{2}{c}{ Independent sample t test } \\
\cline { 5 - 6 } & & & & $\mathbf{T}$ & Sig. \\
\hline Male & 114 & 26.3246 & 3.96555 & \multirow{2}{*}{0.543} & 0.124 \\
Female & 119 & 25.4370 & 4.76150 & \\
\hline
\end{tabular}

Table3. Relationship between duration of marriage and marital satisfaction.

\begin{tabular}{lccccccc}
\hline Question & $\mathbf{N}$ & Minimum & Maximum & Mean & Std. Deviation & $\mathbf{r}^{*}$ & Sig. \\
\hline Duration of marriage in years & 236 & 1.00 & 41.00 & 15.826 & 9.81139 & -0.192 & 0.03 \\
\hline
\end{tabular}

${ }^{*} r=$ Pearson's correlation between number of years at marriage and level of marital satisfaction.

1999). This differential experience of marriage would result variation in marital satisfaction. An inquiry was made to compare the marital satisfaction between women/wives and men/husbands. The mean score of husband's marital satisfaction was 26.32 while it was 25.43 for wives. Wives marital satisfaction is quite less than that of the husbands. But, the point here is the difference statistically significant? To check this, independent sample $t$ test was carried out. Accordingly, as depicted on the table below, there is no statistically significant difference in marital satisfaction between men and women $(\alpha=0.124>0.05)$ (Table 2).

Previous research findings regarding gender differences in marital satisfaction have yielded mixed results. McRae and Brody (1989) found that being in a happy marriage is more important to women than men. Haynes et al. (1992) compared men and women on eight different aspects of marital satisfaction and found that men reported significantly higher satisfaction than did women on four of the eight comparisons (the other four comparisons did not yield statistically significant sex differences) (Clements and Swensen, 2000). In contrast, Gilford and Bengtson (1979) and Levenson et al. (1993) found no gender differences with regard to marital satisfaction (Clements and Swensen, 2000) which is consistent to finding of the present study.

\section{Marital satisfaction and length of marriage}

It was thought that number of years at marriage might have an implication on the marital satisfaction of married couples. To check so, various tests were made to confirm it (Table 3). Table 3 indicates the duration of marriage in years and level of marital satisfaction of study participants. Accordingly, as it is depicted, it ranges from 1 to 41 with a mean of 15.8 and standard deviation 9.8. To see the existence of relationship between duration of years at marriage and level of marital satisfaction, Pearson's correlation was computed. As the test statistics indicates, though the relationship is quite weak (since $r<0.5$ ), there is negative relationship between number of years in marriage and couples marital satisfaction $(r=-$ 0.192 and $\alpha=0.03$ ). This implies that as the years at marriage increases, level of marital satisfaction decreases which really needs further investigation to justify. There is still inconsistency among previous researchers concerning the relationship between duration of marriage and marital satisfaction. Most newly married couples report very high satisfaction and any change from that point would probably be in a downward direction (Broderick, 1988). But the study conducted by Huston et al (1986) revealed the opposite by stipulating the substantial decline in reported marital satisfaction during the first year of marriage. In contrary, a research by Steinmetz, Clavan \& Stein (1990) suggests that marital satisfaction declines over the first 10 to 20 years of marriage and then increases again in late adulthood and retirement though an examination of the factors that may contribute to this decline is beyond the scope of this study.

\section{Age and marital satisfaction}

A bivariate correlation between level of marital satisfaction and age of spouses was conducted. The test statistics $(r=-0.178$ with $\alpha=0.006)$ indicates the existence of negative relationship between the two variables. One way ANOVA was conducted to see whether there is difference in terms of marital satisfaction across the different age groups. Subsequently, significant difference has been witnessed in marital satisfaction across the different age groups which needs further investigation (Table 4). The Post hoc result shows that significant difference in marital happiness was witnessed between those who are within the age group 20 to 30 and 31 to 40 $(\alpha=0.001), 20$ to 30 and 41 to $50(\alpha=0.49)$, as well as between age group 20 to 30 and 51 to 60 ( $\alpha=0.004)$. Otherwise, the difference is insignificant among others.

\section{Educational status and marital satisfaction}

To check whether there is difference in terms of marital 
Table 4. Post hoc test of age group and marital satisfaction.

\begin{tabular}{lcccc}
\hline (I) Age of respondents & $\begin{array}{c}\text { (J) Age of } \\
\text { respondents }\end{array}$ & Mean difference (I-J) & Std. Error & Sig. \\
\hline \multirow{3}{*}{$20-30$} & $31-40$ & 2.93638 & 0.71670 & 0.001 \\
& $41-50$ & $2.23039^{*}$ & 0.80962 & 0.049 \\
& $51-60$ & $3.46461^{*}$ & 0.96778 & 0.004 \\
& $61-70$ & -0.71930 & 2.51327 & 0.999 \\
$31-40$ & $20-30$ & $-2.93638^{*}$ & 0.71670 & 0.001 \\
& $41-50$ & -0.70599 & 0.73314 & 0.871 \\
& $51-60$ & 0.52823 & 0.90476 & 0.977 \\
& $61-70$ & -3.65568 & 2.48969 & 0.584 \\
$41-50$ & $20-30$ & $-2.23039^{*}$ & 0.80962 & 0.049 \\
& $31-40$ & 0.70599 & 0.73314 & 0.871 \\
& $51-60$ & 1.23422 & 0.98001 & 0.716 \\
& $61-70$ & -2.94969 & 2.51801 & 0.768 \\
$51-60$ & $20-30$ & -3.46461 & & \\
& $31-40$ & -.52823 & 0.96778 & 0.004 \\
& $41-50$ & -1.23422 & 0.90476 & 0.977 \\
& $51-60$ & -4.18391 & 0.98001 & 0.716 \\
$61-70$ & & & 2.57322 & 0.482 \\
& $20-30$ & 0.71930 & 2.51327 & 0.999 \\
& $31-40$ & 3.65568 & 2.48969 & 0.584 \\
& $41-50$ & 2.94969 & 2.51801 & 0.768 \\
& $51-60$ & 4.18391 & 2.57322 & 0.482 \\
\hline
\end{tabular}

Table 5. Respondents level of marital satisfaction and educational status.

\begin{tabular}{lccccc}
\hline Variable & Sum of squares & Df & Mean square & F & Sig. \\
\hline Between groups & 420.332 & 4 & 105.083 & 5.837 & 0.000 \\
Within groups & 4068.663 & 226 & 18.003 & - & - \\
Total & 4488.996 & 230 & - & - & - \\
\hline
\end{tabular}

satisfaction across educational categories of married couples, One Way ANOVA was employed. Accordingly, the test statistics $(F=5.835, \alpha=0.00$ with $d f=4)$ uncovered the existence of significant difference in relation to level of marital satisfaction across the different educational categories (Table 5). Although the existence of significant difference among various educational categories in relation to level of marital satisfaction was known, it is important to check the existence of difference among the specific groups. To do so, a post hoc test was used and the following test statistics was obtained (Table $6)$.

As it is seen in Table 6, it is simple to understand the existence of significant difference in marital satisfaction between those married couples who has tertiary education and above and other educational categories (can't read and write $\alpha=0.01<0.05$; can read and write $\alpha=0.0 .00<0.05$ and primary school $(\alpha=0.023<0.05))$ except for secondary school which is insignificant $(\alpha=0.36>0.05)$. In addition, as the test statistics on the table clearly shows, there is no significant difference in in the mean score of marital satisfaction between those who can't read and write and can read and write; can't read and write and primary school; primary school and secondary school, and between can read and write and secondary school. As revealed by studies (Guo and Huang, 2005; Pimentel, 2000; Trudel, 2002) like other structural factors, education has a significant effect on marital satisfaction of couples. In this particular study, too, it creates variation on marital satisfaction of couples. Correspondingly, studies conducted by (Kim, 1992; Mirfardi et al., 2010; Vaijayanthimala et al., 2004) also highlighted the prevalence of positive relationship between educational status and marital happiness, that is, higher education achievement implies better marital satisfaction.

\section{Number of children and marital satisfaction}

A study conducted by Rostami (2013) revealed a negative relationship between marital satisfaction and 
Table 6. Post hoc test on level of marital satisfaction and EDUCATIONAL status.

\begin{tabular}{|c|c|c|c|c|}
\hline $\begin{array}{l}\text { (I)Educational status of } \\
\text { respondents }\end{array}$ & $\begin{array}{l}\text { (J) educational status of } \\
\text { respondents }\end{array}$ & Mean difference (I-J) & Std. Error & Sig. \\
\hline \multirow{4}{*}{ Can't read and write } & Can read and write & 0.69844 & 0.76216 & 0.890 \\
\hline & Primary school & -0.82771 & 0.74918 & 0.804 \\
\hline & Secondary school & -1.62929 & 1.04171 & 0.522 \\
\hline & Tertiary school and above & $-3.88754^{*}$ & 0.95933 & 0.001 \\
\hline \multirow{4}{*}{ Can read and write } & Can't read and write & -0.69844 & 0.76216 & 0.890 \\
\hline & Primary school & -1.52614 & 0.82848 & 0.352 \\
\hline & Secondary school & -2.32773 & 1.10013 & 0.217 \\
\hline & Tertiary school and above & $-4.58597^{\pi}$ & 1.02246 & 0.000 \\
\hline \multirow{4}{*}{ Primary school } & Can't read and write & 0.82771 & 0.74918 & 0.804 \\
\hline & Can read and write & 1.52614 & 0.82848 & 0.352 \\
\hline & Secondary school & -0.80159 & 1.09118 & 0.948 \\
\hline & Tertiary school and above & $-3.05983^{\star}$ & 1.01282 & 0.023 \\
\hline \multirow{4}{*}{ Secondary school } & Can't read and write & 1.62929 & 1.04171 & 0.522 \\
\hline & Can read and write & 2.32773 & 1.10013 & 0.217 \\
\hline & Primary school & 0.80159 & 1.09118 & 0.948 \\
\hline & Tertiary school and above & -2.25824 & 1.24487 & 0.368 \\
\hline \multirow{4}{*}{ Tertiary school and above } & Can't read and write & $3.88754^{*}$ & 0.95933 & 0.001 \\
\hline & Can read and write & $4.58597^{\star}$ & 1.02246 & 0.000 \\
\hline & Primary school & $3.05983^{\star}$ & 1.01282 & 0.023 \\
\hline & Secondary school & 2.25824 & 1.24487 & 0.368 \\
\hline
\end{tabular}

number of children, meaning the higher marital satisfaction found in spouses with less number of children. The number of children that married couples own presumably influences their marital happiness. The table below clearly shows the number of children that participants of the study have and its relation with marital happiness. It ranges from null to twelve. Pearson's coefficient of correlation was employed to test the relationship between number of children and marital satisfaction (Table 7).

Children play an enormously significant part in the lives of many married couples and the influence of children in their parents' lives and on their marital relationship is unavoidable, whether it is positive or negative. Some studies have suggested that the presence of young children in the home negatively affects marital satisfaction in many ways but one of the explanations for this is that couples have less time to spend together (Lavee and Shartin, 1996).

As seen in Table 7 one can witness the existence of significant relationship between marital satisfaction and the number of children that couples own. The correlation coefficient $(r=-0.234)$ confirms that existence of negative correlation between number of children and marital satisfaction. Meaning, though weak, as number of children increases, the level of marital satisfaction decreases. The higher marital satisfaction with the lower children corresponds to the findings of some other studies (Twenge et al., 2003; White and Edwards 1990).
Similarly, as Stone and Shackelford (2007), the introduction of a child drastically changes the marital context. Marital satisfaction is influenced by, and has influences on, children. The presence of children in a marriage has the paradoxical effect of increasing the stability of the marriage (when the children are young, at least), while decreasing marital satisfaction. That is, parenthood makes a marriage less happy but more likely to last.

\section{Sex outside marriage and marital satisfaction}

People who anticipate spousal infidelity would be less satisfied with their marriages than people who do not anticipate infidelity. Survey participants were asked about their experience of sex outside marriage. Consequently, the majority $(71.3 \%)$ of them have never had the experience of extramarital sex. $23.8 \%$ and $5 \%$ of them had low and high experience of extra marital sex. The ANOVA statistics $(F=5.467$ and sig. $=0.00)$ implies the existence of significant difference among the groups of experience of extra-marital sex (high, low, and none) in terms of marital happiness of couples (Table 8 ).

\section{Marriage type and marital satisfaction}

As seen in Table 9, the majority (60\%) of married couples have parent arranged marriage type and the remaining 
Table 7. Number of children and marital satisfaction.

\begin{tabular}{|c|c|c|c|c|c|c|}
\hline \multirow{2}{*}{ Variable } & & \multirow{2}{*}{$\begin{array}{l}\text { The number } \\
\text { of children }\end{array}$} & \multirow{2}{*}{$\begin{array}{c}\text { marital } \\
\text { satisfaction }\end{array}$} & \multicolumn{3}{|c|}{ Number of children spouse owned } \\
\hline & & & & Maximum & Minimum & Mean \\
\hline \multirow{3}{*}{$\begin{array}{l}\text { The number of } \\
\text { children }\end{array}$} & Pearson correlation & 1 & -.234 & 12 & 0 & - \\
\hline & Sig. (2-tailed) & - & 0.000 & - & - & 4.6979 \\
\hline & $\mathrm{N}$ & 235 & 228 & - & - & - \\
\hline \multirow{3}{*}{$\begin{array}{l}\text { level of marital } \\
\text { satisfaction }\end{array}$} & Pearson correlation & $-0.234^{* *}$ & 1 & - & - & - \\
\hline & Sig. (2-tailed) & 0.000 & - & - & - & - \\
\hline & $\mathrm{N}$ & 228 & 233 & - & - & - \\
\hline
\end{tabular}

${ }^{* *}$. Correlation is significant at the 0.01 level (2-tailed).

Table 8. Extra marital sex and marital satisfaction.

\begin{tabular}{lccccc}
\hline \multirow{2}{*}{ Response } & \multirow{2}{*}{ Frequency } & Percentage (\%) & \multicolumn{3}{c}{ ANOVA result } \\
\cline { 3 - 6 } & 12 & 5.0 & Df & F & Sig. \\
\hline High & 57 & 23.8 & 228 & & \\
Low & 171 & 71.3 & 232 & 5.467 & 0.00 \\
None & 240 & 100.0 & - & & \\
Total & & & & & \\
\hline
\end{tabular}

Table 9. Distribution of respondents by marriage type and marital satisfaction.

\begin{tabular}{lccccc}
\hline Marriage type & Frequency & Percentage (\%) & $\begin{array}{c}\text { Mean score of marital } \\
\text { satisfaction }\end{array}$ & \multicolumn{2}{c}{ Independent sample t test } \\
\cline { 4 - 5 } & & & 26.92 & Sig. \\
Love based & 95 & 39.6 & 25.21 & 2.923 \\
parent arranged & 143 & 59.6 & - & $(\mathrm{df}=229)$ \\
Total & 238 & 99.2 & 0.004 \\
\hline
\end{tabular}

$40 \%$ have indicated their marital relationship was love based. In addition, the mean score of marital satisfaction for love based married couples is quite greater than those who settled by their parents (26.92>25.21). But, is this difference statistically significant has to be checked. To this regard, the independent sample $t$ test illuminates the existence of a statistically significant difference in terms of marital satisfaction between those couples who established their relationship by love and by their parents; in the sense that love based couples do have better marital happiness than those by arranged marriage. A key informant at Omo Nada justice office revealed that parental arranged marriage mostly affects the marital satisfaction of spouses. That means, mostly parental arranged marriage involves predetermined action of marriage in which the bride and the groom do not know each other. This condition may create marital dissatisfaction of couples since they are involved in marriage without their consent rather by the knowledge and interest of their parent. The informant further stated:

"....in this district, parents of bride give their daughter to the religious leader because his status/prestige."
However, this condition is inconsistent with the Revised Family Code (2000) which clearly stipulates the need to secure the consent of both sides to settle marriage. Similarly, other informants underscored that love marriage, too, affects marital satisfaction of spouses in different way.

This type of marriage sometimes involves the agreement between couples without the knowledge of the economy of bride and groom. Hence, their marriage may fall in to disagreement because of economic problems. This in turn leads to marital discontent among couples and their marriage may be in question. An informant from AgarodistrictJustice Office stated that civil marriage is more preferable than religious parent arranged marriage. In his own word;

In religious marriage there is no much freedom for bride to defend her rights. Because most of the time the parents of bride simply give their daughter to Sheekii (religious leader of Muslims) without considering the further consequences reach up on this daughter. This means in Jimma zone, Sheekii is the most influential person in Muslim religion. But this marriage have its own 
Table 10. Respondents' habit of participation in leisure activities.

\begin{tabular}{lcccc}
\hline Do you spend leisure together? & Frequency & Percent & Mean of marital satisfaction & Level of Sig. \\
\hline Yes & 117 & 48.8 & 27.9 & \\
No & 122 & 50.8 & 23.9 & 0.000 \\
Total & 239 & 99.6 & Mean difference: 4 & \\
\hline
\end{tabular}

negative impacts on marital satisfaction of women since there would be significant age difference between couples and parental arranged manage has significant influence on the couples because it may involve early marriage.

As it is understood from the qualitative participants, in parental arranged marriage, couple are tied together without love. In this process parents give due emphasis on religious, economic, and social background. Hence, they fail to understand the true meaning of marriage. In this parental arranged marriage, giving high priority to economic and religion take a tempo but fail to consider others elements (things) such as age, love or affection. So that age and love/affection can affect marital satisfaction of couples. This means, if there is age difference and low level of love between couples, there would be marital dissatisfaction thereby resulted in divorce in long run.

\section{Leisure spending and marital satisfaction}

Respondents were asked whether they have the habit of refreshing themselves in leisure activities with their spouses with the assumptions that spouses who are pleased with their relationship are more likely to spend leisure activities together (Table 10).

As clearly depicted in Table $10,51 \%$ of the survey respondents have no the habit of leisure time while $49 \%$ of them do. In addition, it the mean score of marital satisfaction of those who spend leisure together with spouse (mean=27.9) is greater than those who don't (mean=23.9). The independent sample $t$ test discloses the existence of significant difference in terms of marital satisfaction between those who said yes and no. From this one can draw that if couples are happy with marital relationship, they are more likely to have leisure activities with their spouse. As Orthner et al. (1993) indicated, leisure activities play a significant role in relationship formation and maintenance. In this regard, respondents' decision/preference to leisure time was asked and found out that $74.6 \%$ need to stay at home while the remaining $24.6 \%$ opt to be on the go and spend leisure time together with their partner.

Besides, a statistically significance difference in marital satisfaction between the two categories was observed. Meaning, a spouse who is pleased in his marital satisfaction eagers and decides to spend leisure together with his/her marital partner. Researches overwhelmingly provides support for the conclusion that couples who share joint leisure activities are more satisfied with their marriages than couples who do not (Zabriskie and McCormick, 2001). Joint leisure activities require a high degree of interaction for successful completion of the activity and tend to open communication and encourage role interchange" (Orthner, 1975). The following table provides an insight concerning this issue (Table 11).

\section{Interest difference and marital satisfaction}

Respondents were asked regarding interest similarities with their marital couples. Consequently, $67.5 \%$ of the survey participants revealed that their interests had never been different followed by very few of their interests $(20.8 \%)$, some of them $(10.4 \%)$ and 3 respondents $(1.3 \%)$ replied that all of their interests are quite different. To determine the existence of difference in marital satisfaction among respondents who said all of them, some of them, very few of them and none of them, one way ANOVA was conducted. As the test statistic $(F=12.663$, alpha $=0.000)$ tells us, there is statistically significant difference in marital happiness across the couples degrees of interest dissimilarity. The upcoming table elucidates the issue in a straight forward manner (Table 12).

\section{Openness and marital satisfaction}

Empirical works indicated that openness among married couples matters much in the marital happiness of couples. A spouse who is open to all issue for one's marital partner signifies that he/she is happy with his/her relationship (Table 13).

Regarding the disclosure of issues among mates, only $9.2 \%$ of the participants revealed as they are open in everything and $26.7 \%$ of them are open in most things for their mate. While $32.9 \%$ of the married couples were rarely open to their mates, sizable number of respondents $(31.3 \%)$ never discloses everything for their marital partner. The One way ANVA test testifies the prevalence of a statistically significant difference in marital satisfaction across the different levels of openness of spouses for their marital satisfaction. 
Table 11. Respondents' preference to leisure time.

\begin{tabular}{lccccc}
\hline $\begin{array}{l}\text { Decision during } \\
\text { leisure time }\end{array}$ & Frequency & $\begin{array}{c}\text { Percentage } \\
(\%)\end{array}$ & $\begin{array}{c}\text { Mean of marital } \\
\text { satisfaction }\end{array}$ & \multicolumn{2}{c}{ Independent sample $t$ test } \\
\cline { 5 - 6 } To be "on the go" to & 59 & 24.6 & 28.73 & S & Sig. \\
leisure & 179 & 74.6 & 24.95 & $6.036(\mathrm{df}=229)$ & 0.000 \\
Stay at home & 238 & 99.2 & - & & \\
Total & &
\end{tabular}

Table 12. Extent of interest dissimilarity among marital partners and marital satisfaction.

\begin{tabular}{lcccc}
\hline $\begin{array}{l}\text { Interest } \\
\text { dissimilarity }\end{array}$ & Frequency & Percentage (\%) & \multicolumn{2}{c}{ One way ANOVA Result } \\
\hline All of them & 3 & 1.3 & & Sig. \\
Some of them & 24 & 10.0 & & \\
Very few of them & 48 & 20.0 & 12.6663 & 0.000 \\
None of them & 156 & 65.0 & & \\
Total & 231 & 96.3 & & \\
\hline
\end{tabular}

Table 13. Openness and marital satisfaction.

\begin{tabular}{lcccc}
\hline Do you confide in your mate? & Frequency & Percentage (\%) & \multicolumn{2}{c}{ One way ANOVA } \\
\cline { 5 - 6 } Almost never & 75 & 31.3 & & Sig. \\
Rarely & 79 & 32.9 & & \\
In most things & 64 & 26.7 & 34.794 & 0.000 \\
In every thing & 22 & 9.2 & & \\
Total & 240 & 100.0 & & \\
\hline
\end{tabular}

Similarly, as Stone and Shackelford, (2007) clearly stated, being unfaithful can unmistakably cause problems in marriages. Discovered infidelities raise issues of honesty, trust between the partners, commitment, and, ultimately, love. Because a spouse's infidelity has the potential to inflict these emotional costs, marital satisfaction appears to be negatively related to the likelihood that a spouse will be unfaithful.

The qualitative section of the study revealed a set of factors which shape the marital satisfaction of couples. Among others, economic background, educational background, type of marriage, religious background, ethnic background, age difference, place of birth religious hetrogamy, migration, adultery, early marriage, chat abuse, in-laws interference, family size, sexual incompatibility and polygamous marriage are the major factors that determine the marital satisfaction of couples in the study area. Key informants have underscored that economic background is the most important factors in determining the marital satisfaction of couples in the study area. Before concluding marriage, parents of daughter see the wealth of bride or his parents. This situation may affect the marital satisfaction of spouses since there would be age difference and absence of love /intimacy among couples. Besides, the social background of both sides of the parents is duly considered. As discussed previously, economy disturbs marital satisfaction since parents of the bride give high priority to wealthy and prestige rather than age difference among spouses which will ultimately impacts marital satisfaction. A testimony from Dedo district Justice Office pointed that:

During marital engagement, parents of the bride simply look the wealth (income) of the groom without looking its consequences on the relationships of the spouses. That is marriage with advantage-based rather than consent of the bride and groom which will have a detrimental effect on their marital satisfaction. Since their marriage mostly rely on economy than love among couples, their marital satisfaction may decrease when they face economic difficulties.

In relation to religion, as it is understood from informants, religious sameness quite enhances the marital satisfaction of couples. Those couples who are different in their religious affiliation are likely to have less marital happiness. In addition, as Islam is the dominantly followed religion in Jimma zone, believers in the study area has a tendency to miss conceive the dogma of the religion in the wrong way. In his own words, a prosecutor 
Table 14. The effect of poverty on marital satisfaction.

\begin{tabular}{lcc}
\hline Does poverty affect marital satisfaction? & Frequency & Percentage (\%) \\
\hline Yes & 117 & 48.8 \\
No & 123 & 51.3 \\
Total & 240 & 100.0 \\
\hline
\end{tabular}

in Agaro district Justice Office stated that:

It is common to see miss-understanding of the dogma. The religion allows a man to marry more than one wife as long as he can fulfill the basic necessities for his family. However, some followers of the religion may simply marry more than one wives without having resources that enables to subsist his family and falls in to poverty trap. This condition affects the marital satisfaction of couples.

Similarly, polygamous marriage has a great deal in impacting marital satisfaction of spouses. It affects couples relationships in that the husbands may love one of his wives only. In this situation, there might be the prevalence of different kinds of problems like sexual incompatibility between husbands and his wives, ultimately leads to dissatisfaction on one's marital life thereby divorce (Personal Communication in Omo Nada Justice Office, 2014).

Khat abuse has also a pervasive effect in creating marital dissatisfaction in the study area. A prosecutor in Agaro town explained that "Khat abuse reduces the sexual desire of husbands towards his wife. Besides, this as he spends much time on chewing Khat, he exposed to economic crisis since he only spend time on chewing than engaging in income generating activities." Hence, since Khat abuse put couples and family members in poverty and may create sexual incompatibility among coupes, it is adversely affecting marital satisfaction of couples in the study area.

Though the factors that shape marital satisfaction among urban and rural couples is not mutually exclusive, a slight difference has been observed as it is obtained from the qualitative wing of the study. Educational background, love or affection, high cost of living, adultery, illegal migration and incompatibility of status of couples is the most determinant factors pronounced in urban areas. Rural couples mainly influenced by factors such as economy, polygamy and poverty, age difference, parent arranged/religious marriage, early marriage, religiosity, ethnicity, place of birth, family size and social status/prestige.

\section{Poverty and marital satisfaction}

The other inquiry of this study was on how much poverty predicts marital satisfaction. With this respect, respondents were asked whether poverty affect marital satisfaction or not. While $51.3 \%$ of the surveyed respondents feel that poverty will not shape marital satisfaction, where as $48.8 \%$ of them stated that poverty will negatively affect marital satisfaction (Table 14).

From the qualitative inquiry, an in-depth understanding whether the poverty leads to marital dissatisfaction or not was obtained. Consistent to the quantitative one, the qualitative evidence supports both of the directions; while some said poverty brings marital discontent other said poverty could never determine marital dissatisfaction. One of the key informant stated that:

Poverty enforces either husband or wife to be apart from each other and getting marry more than one which in turn affects marital satisfaction. If they earn low income, they quarrel each other because of failure to meet basic needs for their family members. In this case there might be tendency to nagging each other, disputes, spouse abuse and absence of intimacy. This may lead to physical injury to body of wife/violence and ultimately divorce.

Similarly, another key informant endorsed that more or less poverty can affect marital satisfaction of spouses in the following ways.

Poverty leads to migration of women/men to other places. For instance, in this district; mostly either of the spouses migrate to win their poverty with the consent of both couples. But if the migrant spouse stayed there for a long period of time, there is a tendency to decrease love with each other and the spouses may enter into adultery. Finally, when returned, they may dissolve their marriage.

From this we can draw that the existence of poverty within a family will lead to either of the couples to migrate and leads to marital dissatisfaction. One key informant stated that

"if there is poverty one of the couple may migrate Arab countries, especially the wives. When she returns from abroad, she may neglect/ disagree with him since she might come up with various norms and values which are quite different from here."

A prosecutor in Agarodistrict Justice Office underscored the immense effect of poverty on marital satisfaction. He stated that

"love has a meaning if it is supported by wealth. There is 
a saying that "love is the base of everything. But practically, marriage without economy lost its meaning. Because material resources are the basic requirement for one's family life."

This shows how living within the poverty determines marital content among couples. Unlike others, an older informant at Omo Nada district is sceptical with the issue that poverty could adversely affect marital satisfaction of couples. He stated that:

Poverty could never make family members aggressive. Rather, if they tolerate, they can overcome difficulties through working hard. Since poverty is not naturally gifted, one can become a wealthier. If God allows, it is easy to accumulate money and leading a luxurious life. If there is agreement, the duration of poverty would be brief. In general poverty may/may not affect marital satisfaction. But it depends on the agreement and determination of the couples.

Similarly, an elderly informant from Dedo district stated that

"In the absence of basic needs, couples may dissatisfy. Poverty doesn't necessarily affect marital satisfaction because if there is love, it is possible to be rich by working hard. Hence economy is in the right hand of love and agreement."

Thus, the qualitative data generated through in-depth interview empowers the researchers to know the influence of poverty on marital satisfaction has a contradictory pattern.

\section{Implications for policy and research}

The pervasive effect of arranged marriage is highly practiced in the study area. About $60 \%$ of the study participants disclosed that they set their marital engagement through their parents which would have an implication on the married couple's happiness in their marital relationship. Policy level interventions should be commenced to address this customary practice which ultimately determines the prevalence of successful family institution. Thus, a persistence awareness creation campaign on the significance and pertinence of love based marriage has to be made in the area. Moreover, polygamous marriage is highly affecting marital satisfaction of women's in the study area which really needs an immediate policy response in the area to reconcile the practice with the family code of the region in particular and family code of the country in general. The forthcoming research endeavors should prioritize to figure out the multifaceted challenges and impacts of Khat chewing on the marital relationship of couples in particular and the family institution in general. Besides, religious discordant marriage, which is experienced most of the time in urban settings, requires a detailed qualitative inquiry to address the patterns and marital satisfaction of such marriage typology.

\section{CONCLUSION}

Marital satisfaction is determined by a plethora of demographic and social structural factors. Accordingly, factors such as educational status, type of marriage, number of children, differences in social background, sexual incompatibility, interest differences, polygamous marriage, health problems, and conflicts over gender roles were identified as the fundamental factors determining marital satisfaction of couples of the study community. In addition, the qualitative part of the study uncovered factors, which are endemic to the study community, like arranged marriage, Khat chewing, polygamous marriage and religious discordant marriage as determinants of marital satisfaction.

\section{ACKNOWLEDGMENTS}

The researchers would like to thank Jimma University for its financial support to the realization of the study which this article is drawn. Special thanks to data collectors and informants.

\section{CONFLICT OF INTERESTS}

The authors have not declared any conflict of interests.

\section{REFERENCES}

Adigeb, Mbua (2015). The Influence of Psychosocial Factors on Marital Satisfaction among Public Servants in Cross River State. Global Journal of HUMAN-SOCIAL SCIENCE: G Linguistics \& Education 15:8 Version 1.0. Online ISSN: 2249-460x

Rostami A (2013). Marital satisfaction in relation to social support, coping, and quality of life in medical staff in Tehran, Iran. Doctoral dissertation, Umeå university.

Broderick CB (1988). Marriage and the Family (3rd ed). New Jersey: Prentice Hall.

Brubaker TH, Kimberly JA (1993). Challenges to the American family. In T. H. Brubaker's (Ed.), Family relations: Challenges for the future (pp. 3-16). Newbury Park, CA: Sage.

Clements R, Swensen CH (2000). Commitment to one's spouse as a predictor of marital quality among older couples. Curr. Psychol. 19(2):110-120

Faulkner R (2002). Gender-Related Influences on Marital Satisfaction and Marital Conflict over Time for Husbands and Wives. University of Georgia, Athens, Georgia. Dissertation.

Federal Negarit Gazetta Extra Ordinary Issue No. 1/2000 (2000). The Revised Family Code Proclamation No. 213/2000 Addis Ababa.

Gilford B (1979). Measuring Marital Satisfaction in Three Generations: Positive and Negative Dimensions. J. Marriage Family 41(2):387

Guo B, Huang J (2005). Marital and sexual satisfaction in Chinese families: Exploring the Moderating Effects. J. Sex Marital Ther. 31(1):21-29.

Heaton TB, Blake AB (1999). Gender differences in determinants of 
marital disruption. J. Family Issues 20(1):25-46.

Lavee Y, Sharin S (1996). The effect of parenting stress on marital quality. J. Family issues 17(1):114-136.

Macionis J (2008). Sociology. 12th edition. Pearson Hall.

Mathews M (2002). A study of factors contributing to marital satisfaction. Department of Psychology University of Zulu land. http://hdl.handle.net/10530/449

McRae J, Brody C (1989). The differential importance of marital experiences for the well-being of women and men. Soc. Sci. Res. 18:237-248

Orthner D, Barnett-Morris L, Mancini J (1993). Leisure and family over the life cycle. In L'Abate, L. (Ed.), Handbook of Developmental Family Psychology and Psychopathology. New York: Wiley. pp. 176201

Parson T, Bales R (1955). Family, socialization and Interaction Process. The free press: a division of Macmillan publishing co.Inc. New York

Pimentel EE (2000). Just how do I love thee? Marital relations in urban China. J. Marriage Family 62(1):32-47.

Levenson RW, Carstensen LL, Gottman JM (1995). Emotional Behavior in Long-Term Marriage. Psychol. Aging 10(I):140-149.

Steinmetz SK, Clavan S, Stein KF (1990). Marriage and Family Realities Historical and Contemporary Perspectives. New York: Harper \& Row.
Tazekand S, Nafarb G, Keramati T (2013). The relationship between marital satisfaction and job satisfaction among employees of Social Welfare Organization at Tehran Branches. Life Sci. J. 10(6):804-812.

Trudel G (2002). Sexual and marital life: Results of a survey. J. Sex Marital Ther. 28(3):229-249.

Twenge JM, Campbell WK, Foster CA (2003). Parenthood and marital satisfaction: A meta-analytic review. J. Marriage Family. 65:574-583.

White L, Edwards JH (1990). Emptying the nest and parental wellbeing: An analysis of national panel data. Am. Sociol. Rev. 55:235242.

Zabriskie R, McCormick B (2001). The influences of family leisure patterns on perceptions of family functioning. Family Relat. 50:281289. 